\title{
Two New Shallow-water Species of Agathotanais (Crustacea: Tanaidacea) from Japan
}

\author{
Keiichi Kakui ${ }^{1,3}$ and Hisanori Kohtsuka ${ }^{2}$ \\ ${ }^{1}$ Faculty of Science, Hokkaido University, \\ N10 W8, Sapporo 060-0810, Japan \\ E-mail:kakui@mail.sci.hokudai.ac.jp \\ ${ }^{2}$ Misaki Marine Biological Station, Graduate School of Science, University of Tokyo, \\ 1024 Miura 238-0225, Japan \\ ${ }^{3}$ Corresponding author
}

(Received 17 November 2014; Accepted 24 March 2015)

\begin{abstract}
We describe two shallow-water species of Agathotanais, A. misakiensis sp. nov. and A. toyoshioae sp. nov., from Japan. Agathotanais misakiensis was collected from 211-493 m depth in the Sagami Sea, North Pacific Ocean. It closely resembles A. ghilarovi Kudinova-Pasternak, 1989, but differs in having shorter pereonites 3 and 4, all pleonites narrower than pereonite 6, and a shorter article 3 in the antennule. Agathotanais toyoshioae, collected from $95 \mathrm{~m}$ depth in the Genkai Sea, Sea of Japan, is very similar to A. spinipoda Larsen, 1999. The former can be distinguished from the latter by its narrower pleonites, the presence of a ventral keel on pleonites 1 and 2, and the presence on the basis and absence on the carpus and propodus of small spines on pereopods 4-6.
\end{abstract}

Key Words: Tanaidacea, Agathotanaidae, Agathotanais, new species, Japan, key.

\section{Introduction}

The tanaidacean family Agathotanaidae consists of six genera (Błażewicz-Paszkowycz and Bamber 2012; Jóźwiak and Jakiel 2012), one of which is Agathotanais Hansen, 1913. Agathotanais differs from the other five genera in having one or two articles in the antenna, and fine setae covering the body and appendages. It seems to be a bathyal and abyssal taxon; as all previous studies have reported Agathotanais from deeper than $400 \mathrm{~m}$ depth, except for a single specimen of Agathotanais ingolf Hansen, 1913 reported by Holdich and Jones (1983) from shallower than $200 \mathrm{~m}$ (Fig. 1 , asterisk). Three species have been reported from around Japan, collected from the Kurile-Kamchatka and Japan Trenches: A. hadalis Larsen, 2007 from 5473-5484 m depth; A. ingolfi from 4895-5240 m depth; and A. splendidus Kudinova-Pasternak, 1970 from $5441 \mathrm{~m}$ depth (Kudinova-Pasternak 1970; Larsen 2007) (Fig. 1).

During faunal surveys in the Sagami Sea (Pacific Ocean) and the Genkai Sea (Sea of Japan), specimens of Agathotanais collected from comparatively shallow waters, at a minimum depth of $95 \mathrm{~m}$, proved to belong to two undescribed species. In this paper we describe these species and present a key to the species of Agathotanais.

\section{Materials and Methods}

The animals from the Sagami Sea were collected in 2012 and 2014 by RV Rinkai-maru (Misaki Biological Marine Station, University of Tokyo) by means of a biological dredge at depths of 211-493 m; the specimen from the Genkai Sea was obtained in 2014 by TRV Toyoshio-maru (Hiroshima University) with a biological dredge from $95 \mathrm{~m}$ depth. Type specimens fixed in 70-99\% ethanol and preserved in 99\% ethanol were deposited in the Zoological Institute, Faculty of Science, Hokkaido University, Sapporo, Japan (ZIHU). Methods of dissection, specimen preparation, light microscopy, scanning electron microscopy (SEM), and drawing were as described in Kakui and Angsupanich (2012). Orientation and morphological terminology here follow Larsen (2003), except that the term "plumose sensory seta(e)" (PSS; Bird 2011) is used instead of "broom seta(e)". Body length (BL) and cephalothorax length were measured from the base of the antennules to, respectively, the tip of the pleotelson and the posterior edge of the carapace; body width was measured at the widest portion of the carapace (i.e., = carapace width: CW); pereonite width was measured across the "pereopod shoulders" (Larsen 1999b), which are lateral projections on the pereonites where the pereopods attach. Measurements were made axially: dorsally on the body, antennules, antennae, and uropods; laterally on the pereopods and pleopods. All measurements in the text are in millimeters, unless noted otherwise. Length and width in congeners were measured from original illustrations, except for the illustrations in Bird and Holdich (1988) for A. ingolfi. The suffixes in the newly proposed Japanese names, viz., '-ka', and '-zoku', represent the taxonomic ranks family and genus, respectively, in the Japanese language. 


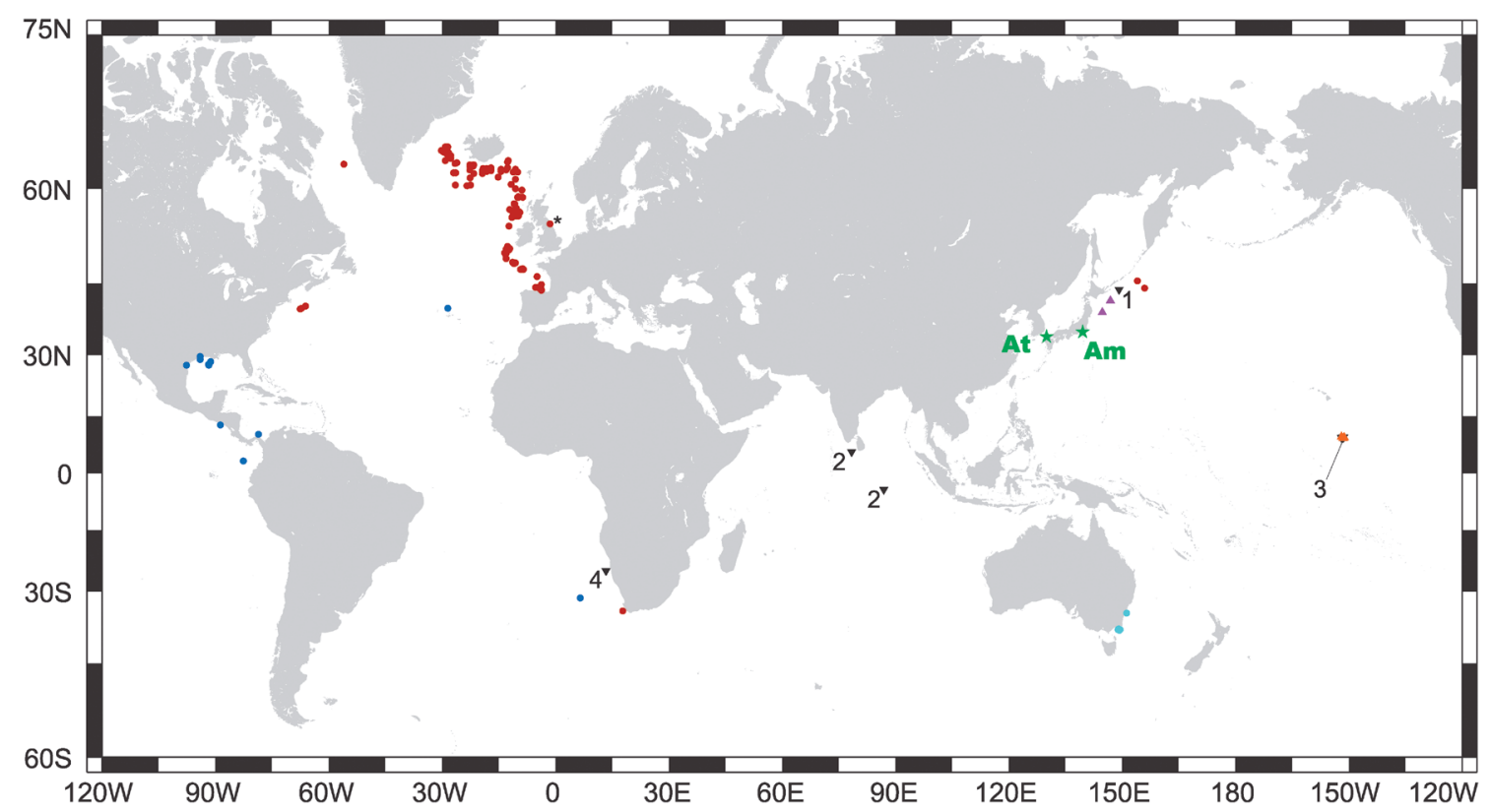

Fig. 1. Map showing the global distribution of Agathotanais. Circles, A. hanseni (blue), A. spinipoda (light blue), and A. ingolf (red); triangles, A. hadalis (purple) and A. ahyongi (orange); inverted black triangles, A. splendidus (1), A. ghilarovi (2), A. manganicus (3), and A. brevis (4); green stars, A. misakiensis sp. nov. (Am), and A. toyoshioae sp. nov. (At); asterisk, the shallow-water $(<200 \mathrm{~m})$ site of Holdich and Jones (1983). Based on data from Hansen (1913); Barnard (1920); Kudinova-Pasternak (1970, 1989, 1990); Lang (1971); Holdich and Jones (1983); Bird and Holdich (1988); Larsen (1999a, b, 2005, 2007); Bird (2010); and this study.

Family Agathotanaidae Lang, 1971

[New Japanese name: Kubire-tanaisu-ka] Genus Agathotanais Hansen, 1913

[New Japanese name: Kubire-tanaisu-zoku] Agathotanais misakiensis sp. nov.

[New Japanese name: Misaki-kubire-tanaisu]

(Figs 2-9)

Material examined. Holotype. Female, ZIHU-4948, BL 3.88, CW 0.53, 4 slides and 1 vial, RV Rinkai-maru, off Misaki, Sagami Sea, North Pacific Ocean, $35^{\circ} 06.086^{\prime} \mathrm{N}$, $139^{\circ} 34.232^{\prime} \mathrm{E}$ to $35^{\circ} 05.807^{\prime} \mathrm{N}, 139^{\circ} 34.089^{\prime} \mathrm{E}, 238-291 \mathrm{~m}$ depth, 19 February 2014, coll. by K. Kakui.

Allotype. Male, ZIHU-4949, BL 2.79, CW 0.41, 4 slides and 1 vial, same collection data as for holotype.

Paratypes. 10 females: ZIHU-4950, BL 3.37, CW 0.47, 4 slides and 1 vial; ZIHU-4951, BL 3.17, CW 0.45, 4 slides and 1 vial; ZIHU-4952, 3 slides and 1 vial; ZIHU-4953, 4 slides and 1 vial; ZIHU-4954, BL 3.12, CW 0.41, 1 vial (body and detached antennule and antenna); ZIHU-4955, BL 3.18, CW $0.44,1$ vial (body and detached antennule and pereopod); ZIHU-4956, BL 3.12, CW 0.44, 1 vial (body and detached antennule); ZIHU-4957, BL 3.03, CW 0.40, 1 vial (body and detached antennule); ZIHU-4958, 1 SEM stub and 1 vial; ZIHU-4959, BL 3.08, CW 0.43, 1 SEM stub. 3 males: ZIHU-4960, BL 2.66, CW 0.38, 1 vial (body and detached antennule); ZIHU-4961, BL 2.68, CW 0.39, 1 vial (body and detached antennule); ZIHU-4962, BL 2.72, CW 0.39, 1 vial (body and detached antennule). 4 females (including 2 anterior parts) and 4 males, ZIHU-4963, 1 vial. ZIHU-4960: RV Rinkai-maru, $35^{\circ} 07.084^{\prime} \mathrm{N}, 139^{\circ} 34.000^{\prime} \mathrm{E}$ to $35^{\circ} 07.112^{\prime} \mathrm{N}$, $139^{\circ} 34.146^{\prime}$ E, 258-211 m depth, 23 January 2014, coll. by H. Kohtsuka. ZIHU-4950-3, 4958, 4959, 4963: same collection data as for holotype. ZIHU-4954-4957, 4961, 4962: RV Rinkai-maru, $35^{\circ} 07.301^{\prime} \mathrm{N}, 139^{\circ} 33.365^{\prime} \mathrm{E}$ to $35^{\circ} 07.327^{\prime} \mathrm{N}$, $139^{\circ} 32.978^{\prime} \mathrm{E}, 250-493 \mathrm{~m}$ depth, 24 February 2012, coll. by M. Shimomura.

Diagnosis. Body narrow (BL/CW more than 6.50); cephalothorax length longer than CW; length/width of pereonites 3 and $40.90-1.00$ and $0.95-1.10$, respectively; pleonites narrower than pereonite 6; pleonites 1 and 2 without ventral keel. Antennular article 3 1.80-2.05 (female) or 2.20-2.60 (male) times as long as antennular article 2. Antenna with one article. Fixed finger with one ventral simple seta. Basis of pereopods 1-6 lacking dorsal small spines. Carpus of pereopods 1-3 with one dorsodistal simple seta; that on carpus of pereopod 2 short (shorter than two-thirds of propodus length). Dactylus of pereopods 1-3 naked. Carpus and propodus of pereopods 4-6 with two and three distal spiniform setae, respectively, but lacking ventral small spines. Uropod with one articulation between basal article and tip.

Etymology. The specific name is an adjective referring to the type locality.

Description of females. Based primarily on holotype, with some observations from paratype ZIHU-4950.

Body (Figs 2A, a1, C, 8, 9) cylindrical, 7.35 times as long as wide, pitted and setulate on cephalothorax and pereon (e.g., Fig. 8A, B). Cephalothorax 0.15 times as long as BL, 1.20 times as long as wide, oval in dorsal view; rostrum triangular; eye lobes absent; posterior region with shallow median ventral groove (cf. Fig. 8A). Length ratio of pere- 

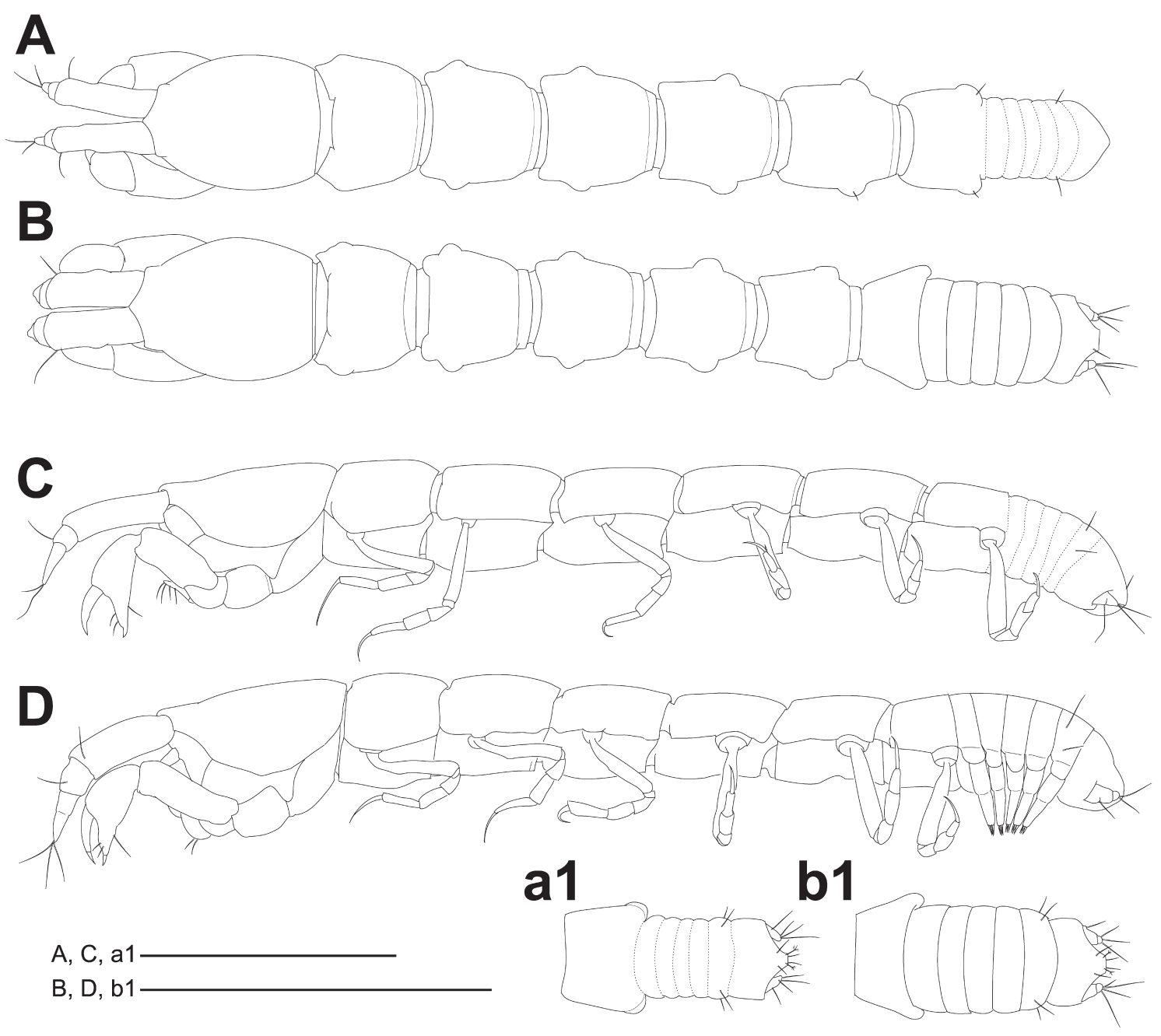

Fig. 2. Agathotanais misakiensis sp. nov. A, C, holotype, female; B, D, allotype. A, B, body, dorsal view; a1, b1, pereonite 6 and pleon of same specimens, dorsal view; C, D, body, lateral view. Scale bars: $1 \mathrm{~mm}$.

onites $1-61.00: 1.20: 1.20: 1.20: 1.20: 0.90$; length/width of pereonites $1-60.75,0.95,1.00,1.05,1.05$, and 0.85 , respectively. Pleon setulate, 0.15 times as long as BL. Pleonites 0.75 times as wide as pereonite 6, 0.60 times as wide as $\mathrm{CW}$, all wider than long, similar in shape; segmental articulations posterior to articulation between pereonites 5 and 6 all obscure (cf. Fig. 9A); pleonite 5 with two pairs of lateral simple setae. Pleotelson setulate, 0.80 times as long as wide, as wide as pleonites; distal region with two pairs of simple setae and one pair of PSS; apical margin straight.

Antennule (Fig. 3A) as long as cephalothorax; length ratio of articles 1-3 1.00:0.20:0.40. Article 13.50 times as long as wide, with one dorsomedial and two distal simple setae, and several middle and distal PSS. Article 2 with two distal simple setae and one distal PSS. Article 3 with six distal simple setae, one distal PSS, and one distal aesthetasc. Antenna (Fig. 3B) uniarticulate, 0.15 times as long as antennule, bearing two distal simple setae.

Labrum (Fig. 4A) with fine distal setae as illustrated. Mandibles (Figs 4B, C, 8C, D) with membranous molar process bearing small distal projection. Left mandible's incisor (Figs 4B, 8C) with blunt teeth; lacinia mobilis round, fused to body of mandible. Right mandible's incisor (Figs 4C, 8D) with broad triangular apex. Labium (Fig. 4D) with one pair each of lateral setulate projections and distal setulate rounded projections. Maxillule (Fig. 4E, e1) with palp bearing two setae; endite with nine spiniform setae. Maxilla (Fig. 4F) naked. Maxillipeds (Fig. 4G) with domed, cordate bases, each bearing one simple seta at insertion of palp; distal regions of bases separated, covered by fine setae, with one pair of simple setae. Palp article 1 naked; article 2 with two simple setae and one plumose seta; article 3 with one simple seta and two plumose setae; article 4 with one outer subdistal simple seta and five distal setulate setae. Epignath (Fig. $4 \mathrm{H})$ narrow, curved, with one terminal seta.

Cheliped (Fig. 3E) with basis bearing small outer ventroproximal process (Fig. 3E, arrow; Fig. 8A, arrow); portion proximal to process inserted into ventral surface of posterior region of cephalothorax. Merus with one ventral simple seta. Carpus 3.00 times as long as wide, with one dorsodistal simple seta and slight ventromedial projection bearing two simple setae. Chela 1.15 times as long as carpus, 3.00 times as long as wide; propodal palm 1.30 times as long as fixed finger, with one inner simple seta, and one simple seta at 


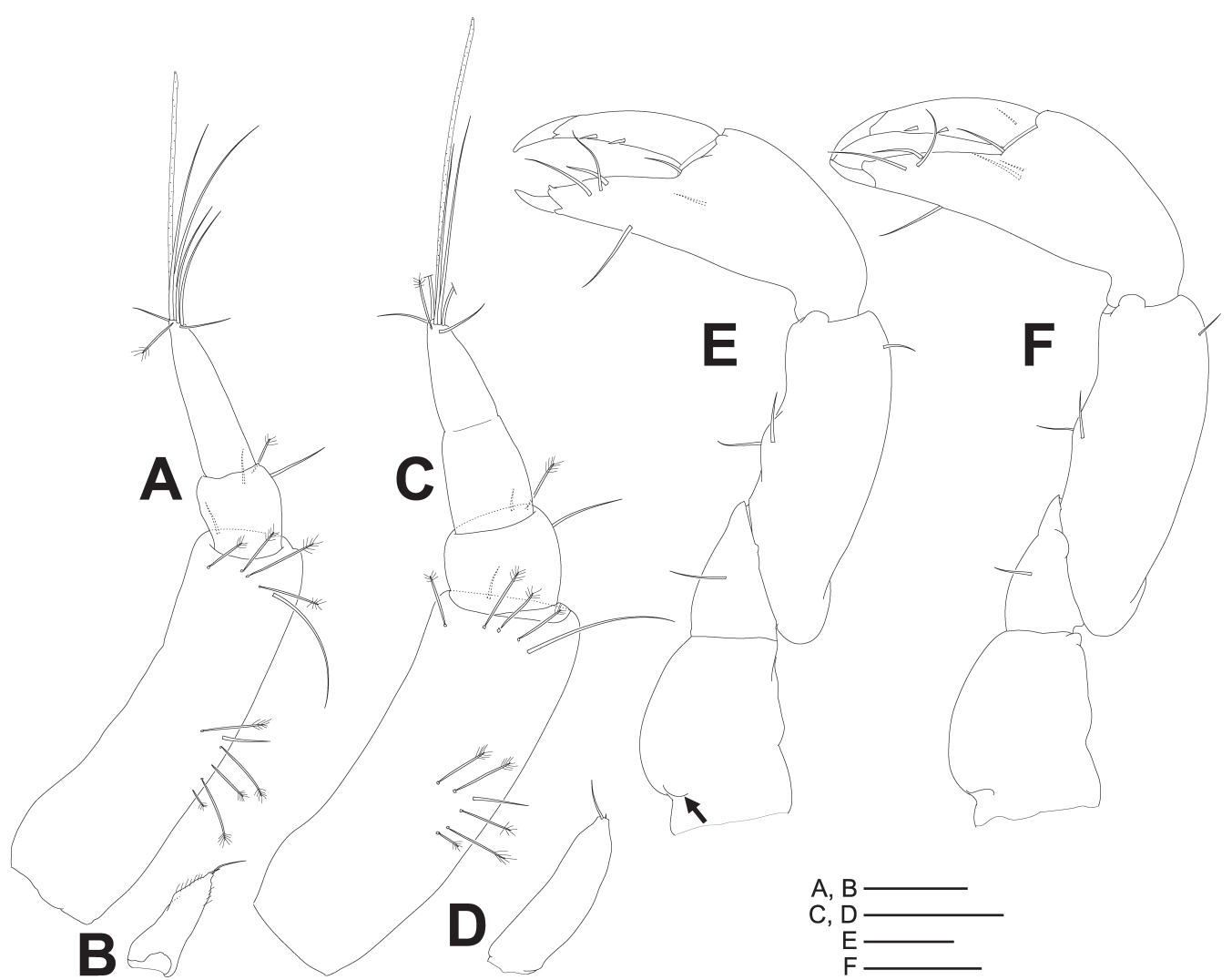

Fig. 3. Agathotanais misakiensis sp. nov. A, B, E, holotype, female; C, D, F, allotype. A, C, left antennule; B, D, left antenna; E, F, left cheliped. Arrow, small outer ventroproximal process on basis. Scale bars: $0.1 \mathrm{~mm}$.

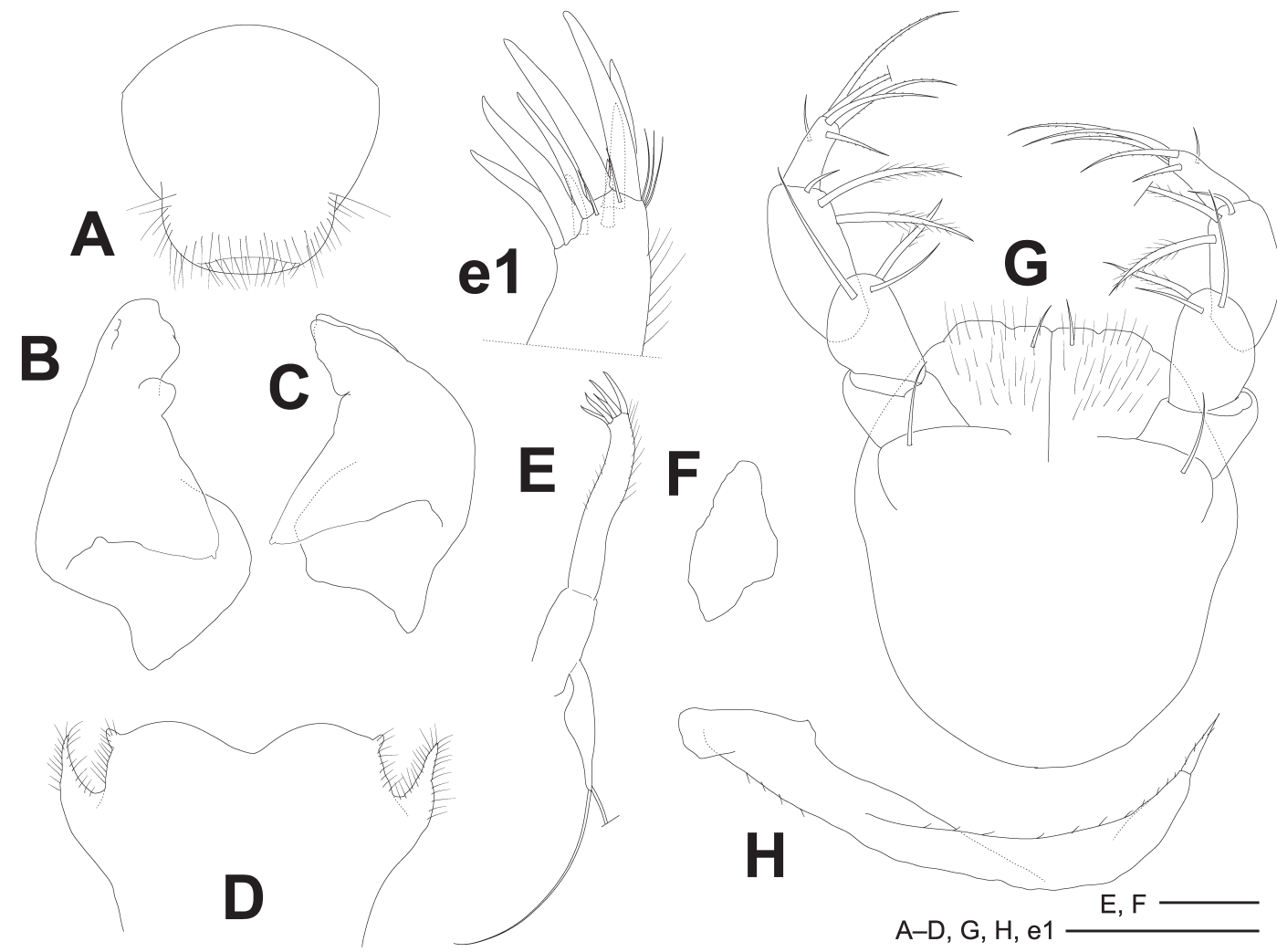

Fig. 4. Agathotanais misakiensis sp. nov. A-G, holotype, female; H, paratype (ZIHU-4950), female. A, labrum; B, left mandible; C, right mandible; D, labium; E, left maxillule; e1, same, tip of endite; F, left maxilla; G, maxillipeds; H, right epignath. Scale bars: A-H, $0.1 \mathrm{~mm}$; e1, $0.05 \mathrm{~mm}$. 


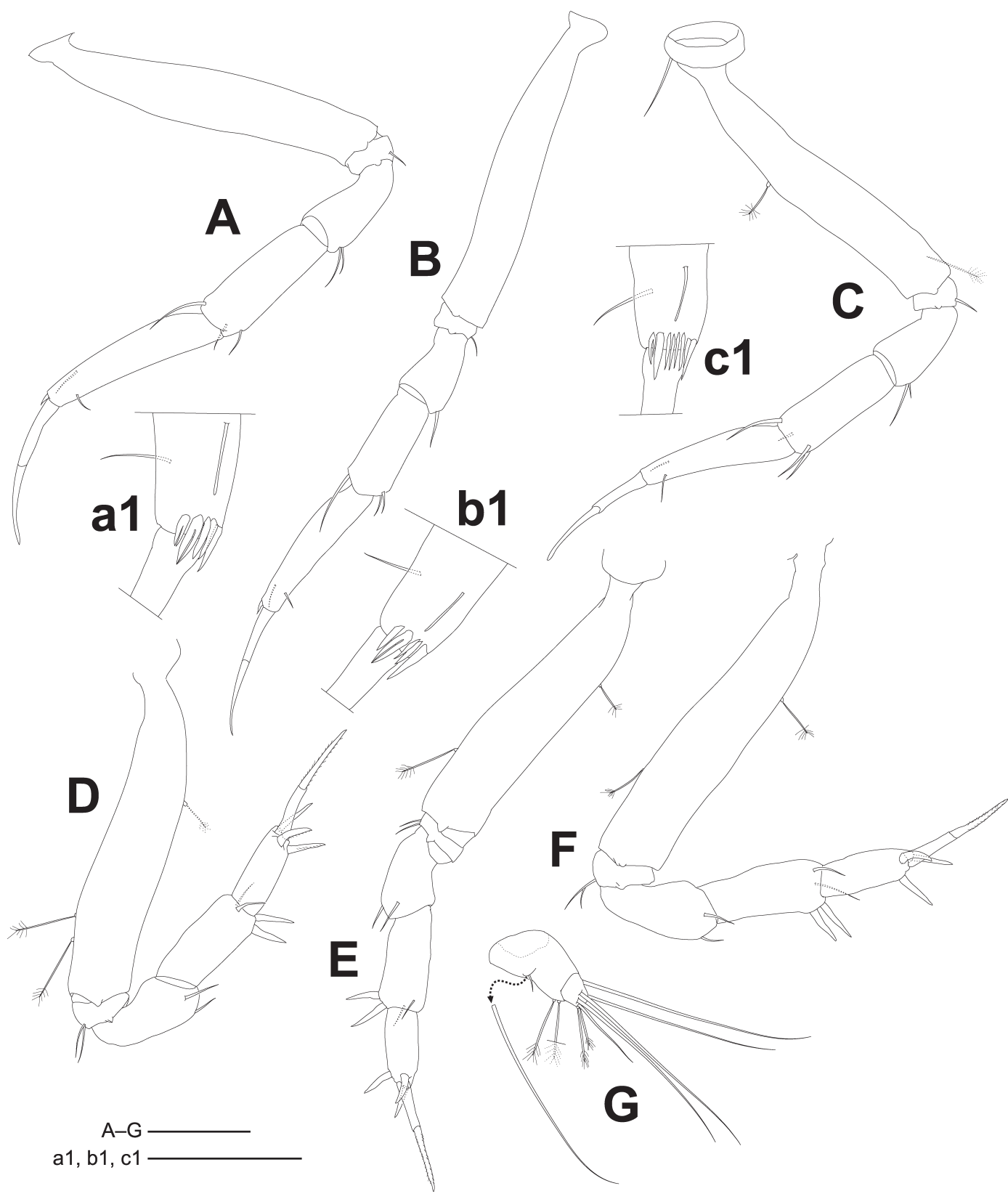

Fig. 5. Agathotanais misakiensis sp. nov., holotype, female. A-F, left pereopods 1-6, outer views; a1, b1, c1, distal parts of propodi of pereopods 1-3, respectively, inner views; $\mathrm{G}$, left uropod. Scale bars: A-G, $0.1 \mathrm{~mm}$; a1, b1, c1, $0.05 \mathrm{~mm}$.

insertion of dactylus; fixed finger with one simple seta on ventral margin and two outer simple setae, one arched spiniform seta, and one distal projection on cutting surface; dactylus as long as fixed finger, with two spiniform setae on cutting surface.

Pereopods 1-6 cylindrical, setulate, with length ratio of $1.10: 1.00: 1.00: 0.90: 0.85: 0.95$. Pereopod 1 (Fig. 5A, a1) 0.23 times as long as $\mathrm{BL}$, with length ratio of basis, ischium, merus, carpus, propodus, and dactylus-unguis 3.6 $5: 0.25: 1.00: 1.55: 1.95: 1.65$. Basis without dorsal spines. Ischium with one ventral simple seta. Merus with two ventral simple setae. Carpus with one dorsodistal and two ventrodistal simple setae. Propodus with one ventro-subdistal simple seta, one dorso-subdistal seta, and inner distal row of complex spiniform setae (Fig. 5a1). Dactylus and unguis subequal in length, naked. Pereopod 2 (Fig. 5B, b1) with length ratio of articles from basis to dactylus-unguis 4.50 : $0.25: 1.00: 1.60: 2.10: 1.80$; similar to pereopod 1 , except merus with just one ventral simple seta. Dorsodistal simple seta of carpus short (shorter than two-thirds propodus length). Pereopod 3 (Fig. 5C, c1) with coxa bearing one simple seta. Length ratio of articles from basis to dactylusunguis $4.45: 0.20: 1.00: 1.70: 2.00: 1.70$; similar to pereopod 2 , except basis with one dorsal and one ventral PSS, merus with two ventral simple setae, and carpus with one inner distal simple seta. Pereopod 4 (Fig. 5D) with length ratio of articles from basis to dactylus-unguis $4.00: 0.30: 1.00: 1.70$ : $1.85: 1.00$. Basis with one dorsal and two ventral PSS. Ischi- 


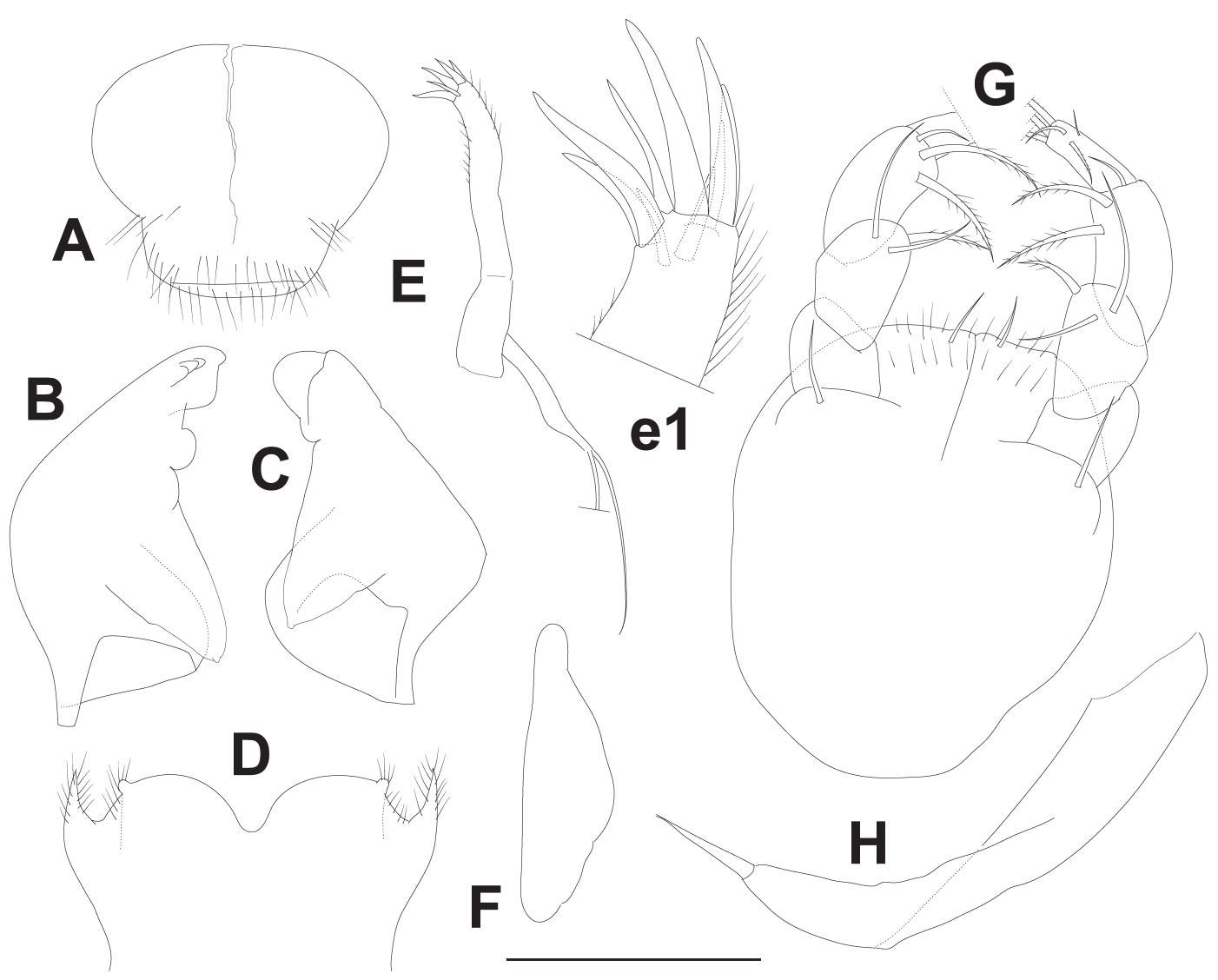

Fig. 6. Agathotanais misakiensis sp. nov., allotype, male. A, labrum (partly broken); B, left mandible; C, right mandible; D, labium; E, left maxillule; e1, same, tip of endite; F, left maxilla; G, maxillipeds; H, left epignath. Scale bar: A-D, F-H, $0.1 \mathrm{~mm}$; E, $0.2 \mathrm{~mm}$; e1, $0.05 \mathrm{~mm}$.

um with two ventral simple setae. Merus with two ventral simple setae. Carpus with one outer and one inner simple setae and two ventrodistal spiniform setae. Propodus with three distal spiniform setae. Dactylus naked. Unguis with row of short setae. Pereopod 5 (Fig. 5E) with coxa naked. Length ratio of articles from basis to dactylus-unguis 4.20 : $0.20: 1.00: 1.25: 1.05: 1.45$; similar to pereopod 4 except basis with just one ventral PSS. Pereopod 6 (Fig. 5F) with length ratio of articles from basis to dactylus-unguis 3.95: $0.25: 1.00: 1.20: 1.00: 1.25$; similar to pereopod 5 .

Pleopods absent.

Uropod (Figs 5G, 9) with exopod fused to basal article, slight, not expanded laterally, bearing two simple setae. Endopod fused to basal article, but with one distal articulation (Fig. 9a1, arrow) between 'proximal' and 'distal' articles; proximal article with two PSS; distal article with five simple setae and two PSS.

Description of males. Based on the allotype.

Body (Fig. 2B, b1, D) similar to female but slightly stouter (6.85 times as long as wide) and with relatively shorter pereonite 6 and wider pleonites. Pereonites $1-6$ with length ratio of $1.00: 1.15: 1.15: 1.15: 1.15: 0.70$; length/width of pereonites $1-60.70,0.90,0.95,1.00,1.00$, and 0.55 , respectively. Pleon length 0.2 times BL. Pleonites 0.80 times as wide as pereonite 6, 0.70 times as wide as $\mathrm{CW}$; articulations evident between all segments. Pleotelson narrower than pleonites.

Antennule (Fig. 3C) as long as cephalothorax, thick- er than that of female; length ratio of articles 1-3 $1.00: 0.20: 0.55$. Articles $1-3$ similar to those of female, except article 3 with groove in middle region. Antenna (Fig. 3D) similar to that of female but relatively longer ( 0.25 times as long as antennule).

Mouthparts (Fig. 6) similar to those of female.

Cheliped (Fig. 3F) similar to that of female, except propodal palm with two inner simple setae, and dactylus with one inner proximal simple seta.

Pereopods 1-6 (Fig. 7A-F) with length ratio of 1.15:1.05: $1.00: 0.95: 1.00: 1.00$; pereopod 10.25 times as long as BL. Pereopods similar to those of female, except: merus of pereopods 1 and 3 with just one ventral simple seta; carpus of pereopod 2 with just one inner distal simple seta.

Pleopods (Fig. 7G) all similar. Basal article naked. Endoand exopods fused to basal article; endopod with six distal and one inner subdistal spiniform setae; exopod with eight distal spiniform setae.

Uropod (Fig. 7H) similar to that of female, except proximal article with three PSS.

Variation. BL/CW 7.00-7.55 in females $(n=7)$, 6.856.95 in males $(n=4)$. Length/width of pereonites 3 and 4 $0.90-1.00$ and $0.95-1.10$, respectively. Relative length of antennular article 3 to article $21.80-2.05$ in females, 2.20-2.60 in males. Measurement data for these three characters listed in Table 1.

Chelipedal basis with one dorsal simple seta in four para- 


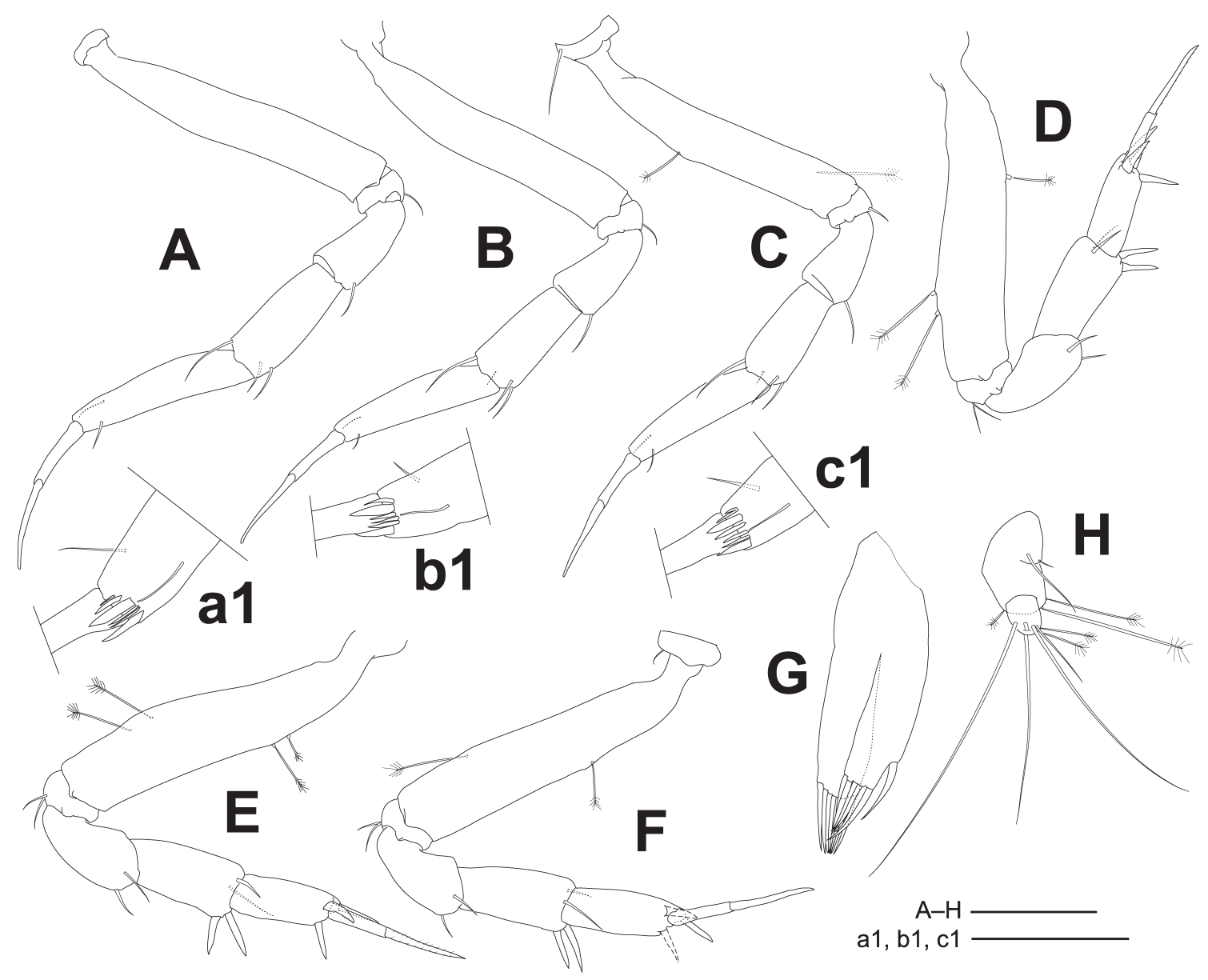

Fig. 7. Agathotanais misakiensis sp. nov., allotype, male. A-F, left pereopods 1-6, outer views; a1, b1, c1, distal parts of propodi of pereopods 1-3, respectively, inner views; $\mathrm{G}$, left pleopod 2; $\mathrm{H}$, left uropod. Scale bars: A-H, $0.1 \mathrm{~mm}$; a1, b1, c1, $0.05 \mathrm{~mm}$.

types. Chelipedal carpus with one dorsomedial simple seta in four paratypes. Merus of pereopod 2 with two ventral simple setae in three paratypes. Carpus of pereopod 2 with one inner distal simple seta in three paratypes and allotype. Basis of pereopod 4 with two ventral PSS in three paratypes and allotype.

Maxillular endite with nine spiniform setae in holotype, allotype and one paratype, and 10 in three paratypes.

Distribution. So far known only from type locality, at depths of 211-493 m.

Remarks. Agathotanais misakiensis sp. nov. is the tenth species described in this genus. In having an articulation between the uropodal basal article and the tip of the endopod, this species closely resembles A. ghilarovi Kudinova-Pasternak, 1989. The former differs from the latter (see Kudinova-Pasternak 1989) in having shorter pereonites (especially pereonites 3 and 4: length/width of both pereonites is about 1.00 in A. misakiensis but about 1.50 in A. ghilarovi); narrower pleonites (pleonites narrower than pereonite 6 in A. misakiensis but as wide as pereonite 6 in A. ghilarovi); a shorter antennular article 3 (in A. misakiensis, 1.80-2.05 times longer than article 2 in females, 2.20-2.60 times longer in males; comparable values for A. ghilarovi 3.05 in females and 3.35 in males); and the setation of the merus and carpus of pereopod 4 (in A. ghilarovi, the merus has four ventral setae, and the carpus lacks ventral setae).

\section{Agathotanais toyoshioae sp. nov.}

[New Japanese name: Toyoshio-kubire-tanaisu]

(Figs 10-14)

Material examined. Holotype. Female with developed oostegites but lacking eggs or embryos, ZIHU-4964, BL 2.25, CW 0.30, 7 slides and 1 vial, TRV Toyoshio-maru, Genkai Sea, Sea of Japan, $34^{\circ} 04.911^{\prime} \mathrm{N}, 129^{\circ} 58.444^{\prime} \mathrm{E}$ to $34^{\circ} 04.891^{\prime} \mathrm{N}, 129^{\circ} 58.479^{\prime} \mathrm{E}, 95 \mathrm{~m}$ depth, 26 May 2014, coll. by S. Ohtsuka.

Diagnosis. Body narrow (BL/CW more than 6.50); cephalothorax longer than $\mathrm{CW}$; length/width of pereonites 3 and 41.05 and 1.15, respectively; pleonites narrower than pereonite 6 (pleonite width 0.65 times pereonite- 6 width, 0.45 times $\mathrm{CW}$ ); pleonites 1 and 2 with ventral keel. Antennular article 32.35 (female) times as long as antennular article 2 . Antenna with one article. Fixed finger with one ventral simple seta. Basis of pereopods 1-6 with dorsal small spines. Carpus of pereopods 1-3 with one dorsodistal simple seta; that on carpus of pereopod 2 short (shorter than two-thirds of propodus length). Dactylus of pereopods 1-3 naked. 


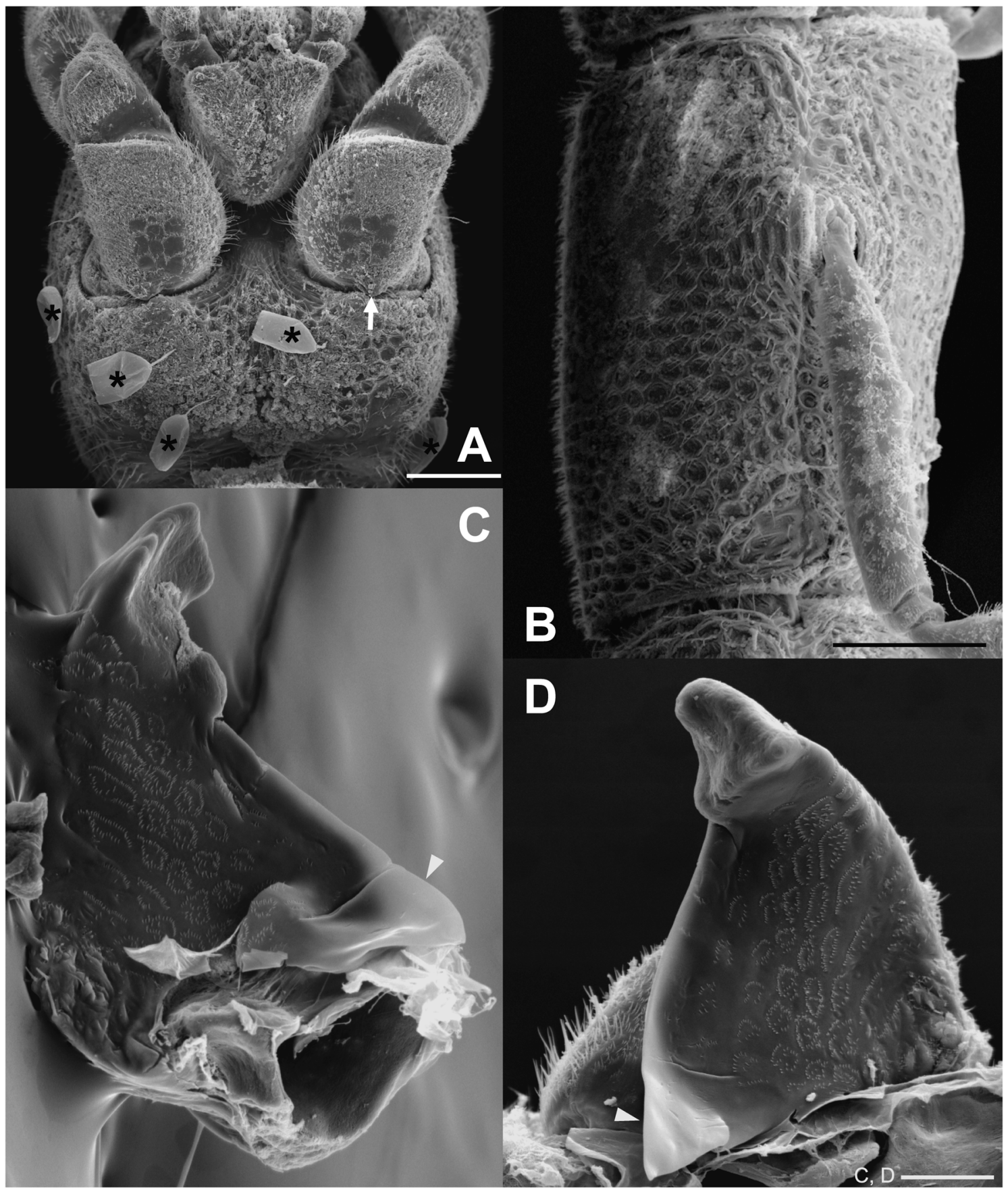

Fig. 8. Agathotanais misakiensis sp. nov., paratypes (A, B, ZIHU-4959; C, D, ZIHU-4958), females, SEM images. A, posterior region of cephalothorax, ventral view; B, pereonite 3 showing pitted surface, right view; C, D, left and right mandibles with membranous molar process (arrowheads), respectively. Arrow, small outer ventroproximal process on basis of left cheliped. Asterisks, peritrich ciliates. Scale bars: A, $\mathrm{B}, 0.1 \mathrm{~mm}$; C, D, $0.02 \mathrm{~mm}$.

Carpus and propodus of pereopods 4-6 with one and three distal spiniform setae, respectively but lacking ventral small spines. Uropod with no articulation between basal article and tip.

Etymology. The species is named after TRV Toyoshiomaru, the ship from which the type specimen was collected.

Description of female. Body (Figs 10, 14) cylindrical, 7.50 times as long as wide, pitted and setulate on cephalothorax and pereon (cf. Fig. 14). Cephalothorax 0.15 times as long as $\mathrm{BL}, 1.30$ times as long as wide, acorn-shaped in dor- sal view; rostrum rounded; eye lobes absent; posterior region with shallow median venral groove (Fig. 14A). Pereonites $1-6$ with length ratio of $1.00: 1.20: 1.20: 1.30: 1.30: 1.00$; length/width of pereonites $1-6,0.75,0.95,1.05,1.15,1.20$, and 1.05 , respectively. Pleon setulate, 0.15 times as long as BL. Pleonites 0.65 times as wide as pereonite 6, 0.45 times as wide as $\mathrm{CW}$, all wider than long, similar in shape; segmental articulations posterior to that between pereonites 5 and 6 all obscure; pleonites 1 and 2 each with ventral keel; pleonites 3 and 4 slightly narrower than others; pleonite 5 with one pair 


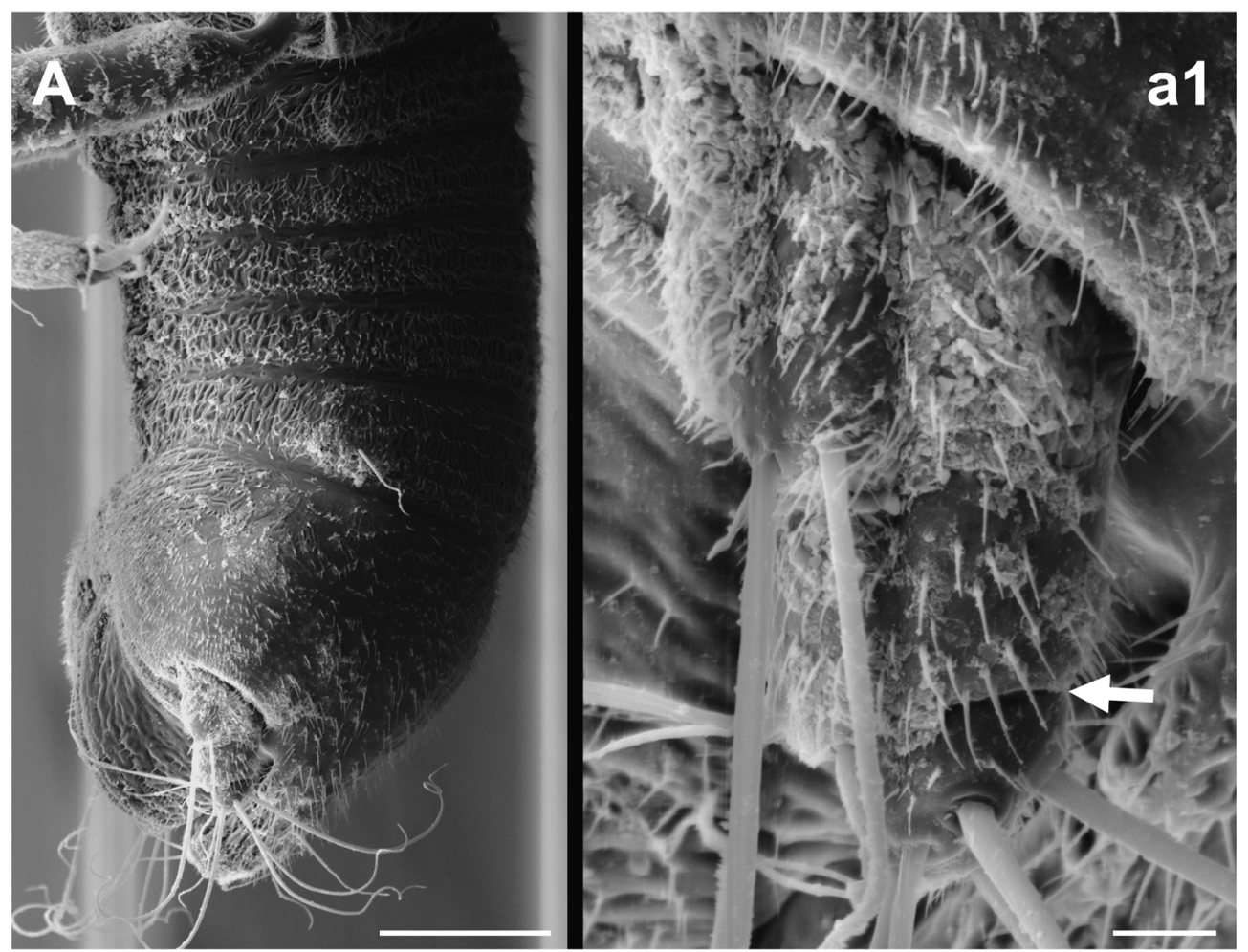

Fig. 9. Agathotanais misakiensis sp. nov., paratype (ZIHU-4959), female, SEM images. A, pleon, left view; a1, higher magnification view showing one articulation in uropod (arrow). Scale bars: A, $0.1 \mathrm{~mm}$; a1, $0.01 \mathrm{~mm}$.

Table 1. Variations in measurements among type specimens.

\begin{tabular}{|c|c|c|c|c|c|c|c|c|}
\hline \multirow{2}{*}{ ZIHU } & \multirow{2}{*}{$\mathrm{BL} / \mathrm{CW}$} & \multicolumn{6}{|c|}{ Length/width of pereonites } & \multirow{2}{*}{$\begin{array}{l}\text { Relative length of } \\
\text { article } 3 \text { to article } \\
2 \text { in antennule }\end{array}$} \\
\hline & & 1 & 2 & 3 & 4 & 5 & 6 & \\
\hline \multicolumn{9}{|l|}{ FEMALES } \\
\hline $4948^{\mathrm{a}}$ & 7.35 & 0.75 & 0.95 & 1.00 & 1.05 & 1.05 & 0.85 & 1.95 \\
\hline 4950 & 7.25 & 0.80 & 1.00 & 1.00 & 0.95 & 0.95 & 0.75 & 1.85 \\
\hline 4951 & 7.00 & 0.75 & 0.95 & 1.00 & 1.05 & 1.10 & 0.75 & 1.95 \\
\hline 4954 & 7.55 & 0.85 & 0.90 & 1.00 & 1.10 & 1.05 & 0.70 & 2.05 \\
\hline 4955 & 7.30 & 0.80 & 0.95 & 0.95 & 1.00 & 1.05 & 0.75 & 1.95 \\
\hline 4956 & 7.10 & 0.75 & 0.85 & 1.00 & 1.05 & 1.10 & 0.80 & 1.80 \\
\hline 4957 & 7.50 & 0.80 & 0.95 & 1.00 & 1.10 & 1.05 & 0.75 & 1.90 \\
\hline \multicolumn{9}{|l|}{ MALES } \\
\hline $4949^{b}$ & 6.85 & 0.70 & 0.90 & 0.95 & 1.00 & 1.00 & 0.55 & 2.60 \\
\hline 4960 & 6.95 & 0.75 & 0.85 & 0.90 & 0.95 & 0.90 & 0.55 & 2.20 \\
\hline 4961 & 6.95 & 0.75 & 0.90 & 0.95 & 1.00 & 0.90 & 0.55 & 2.35 \\
\hline 4962 & 6.95 & 0.75 & 0.90 & 0.95 & 0.95 & 0.95 & 0.50 & 2.50 \\
\hline
\end{tabular}

${ }^{\mathrm{a}}$ Holotype, ${ }^{\mathrm{b}}$ allotype.

of lateral simple setae. Pleotelson setulate, 0.80 times as long as wide, wider than pleonites; distal region with two pairs of simple setae; apical margin straight.

Antennule (Fig. 11A) 1.10 times as long as cephalothorax; length ratio of articles 1-3 1.00:0.15:0.35. Article 1 thick proximally, with one dorsomedial and two distal simple setae, several middle and distal PSS, and several small spines. Article 2 with two distal simple setae and one distal PSS. Article 3 with six distal simple setae, one distal PSS, and one distal aesthetasc. Antenna (Fig. 11B) uniarticulate, 0.20 times as long as antennule, bearing two distal simple setae.

Labrum (Fig. 12A) with fine distal setae as illustrated. Mandibles (Fig. 12B, C) with membranous molar process bearing small distal projection. Left mandible's incisor (Fig. 12B) with blunt teeth; lacinia mobilis triangular, fused to body of mandible. Right mandible's incisor (Fig. 12C) with blunt teeth. Labium (Fig. 12D) with one pair each of lateral 


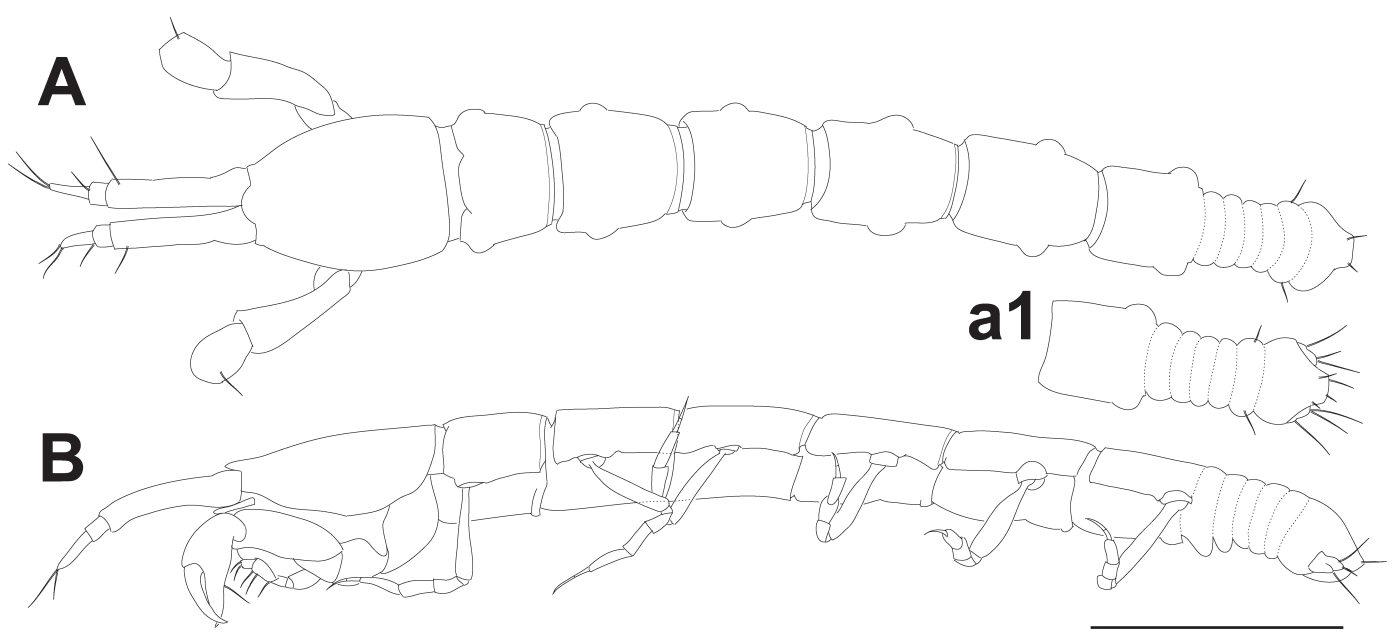

Fig. 10. Agathotanais toyoshioae sp. nov., holotype, female. A, body, dorsal view; a1, pereonite 6 and pleon, dorsal view; B, body, lateral view. Scale bar: $0.5 \mathrm{~mm}$.

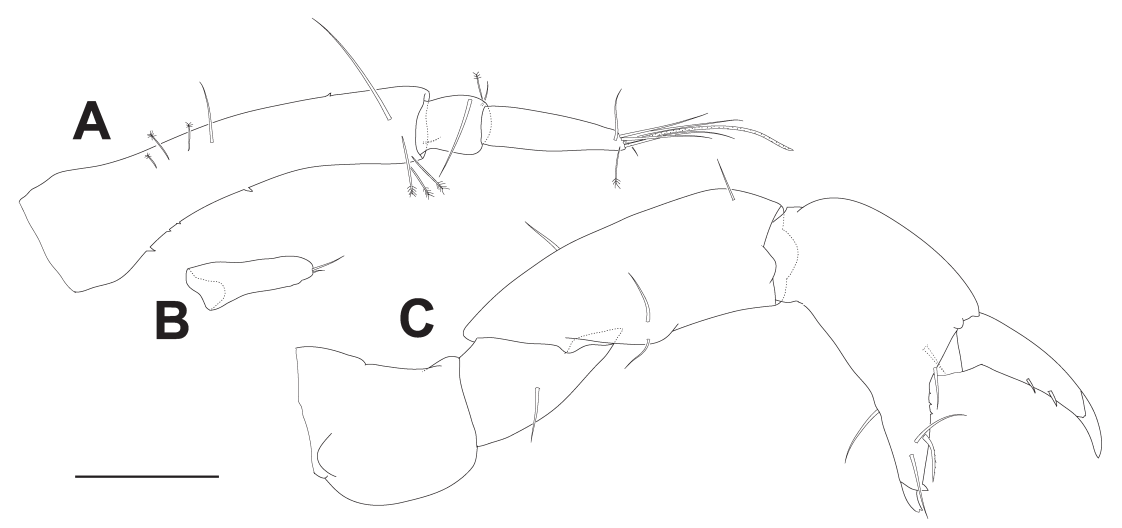

Fig. 11. Agathotanais toyoshioae sp. nov., holotype, female. A, right antennule; B, right antenna; C, right cheliped. Scale bar: $0.1 \mathrm{~mm}$.

and distal setulate projections. Maxillule (Fig. 12E, e1) with palp bearing two setae; endite with 10 spiniform setae. Maxilla (Fig. 12F) naked. Maxillipeds (Fig. 12G) with domed, cordate bases, each bearing one simple seta at insertion of palp; distal regions of bases separated, covered by fine setae, with one pair of simple setae. Palp article 1 naked; article 2 with three simple setae; article 3 with two plumose setae; article 4 with five distal simple setae. Epignath (Fig. 12H) narrow, curved, with one simple terminal seta.

Cheliped (Fig. 11C) with basis bearing small outer ventroproximal process; portion proximal to process inserted into ventral surface of posterior region of cephalothorax. Merus with one ventral simple seta. Carpus 2.15 times as long as wide, with slight ventromedial projection bearing two simple setae, and one dorsomedial and one dorsodistal simple setae. Chela 1.05 times as long as carpus, 2.15 times as long as wide; propodal palm 1.30 times as long as fixed finger, with one inner and one outer simple setae at insertion of dactylus; fixed finger with one simple seta on ventral margin and two outer simple setae, one arched spiniform seta, one distal projection, and several small spines on cutting surface; dactylus as long as fixed finger, with two spini- form setae on cutting surface.

Pereopods 1-6 cylindrical, setulate, with length ratio of $1.20: 1.10: 1.00: 0.95: 1.05: 1.05$. Pereopod 1 (Fig. 13A, a1) 0.20 times as long as $\mathrm{BL}$, with length ratio of articles from basis to dactylus-unguis $3.70: 0.25: 1.00: 1.40: 1.95: 1.65$. Basis with dorsal small spines. Ischium with one ventral simple seta. Merus with two ventral simple setae. Carpus with one dorsodistal and two ventrodistal simple setae. Propodus with one ventro-subdistal simple seta and inner distal row of spiniform setae (Fig. 13a1). Dactylus and unguis subequal in length, naked. Pereopod 2 (Fig. 13B, b1) with coxa bearing one dorsal simple seta. Length ratio of articles from basis to dactylus-unguis $3.65: 0.25: 1.00: 1.35: 1.80$ : 1.55; similar to pereopod 1, except carpus with just one ventral simple seta. Dorsodistal simple seta on carpus short (shorter than two-thirds propodus length). Pereopod 3 (Fig. $13 \mathrm{C}, \mathrm{c1}$ ) with length ratio of articles from basis to dactylusunguis $3.70: 0.25: 1.00: 1.30: 1.95: 1.65$; similar to pereopod 2. Pereopod 4 (Fig. 13D) with naked coxa. Length ratio of articles from basis to dactylus-unguis $4.35: 0.25: 1.00: 1.15$ : $1.05: 2.00$. Basis with one dorsal and two ventral PSS, and dorsal small spines. Ischium with two ven- 


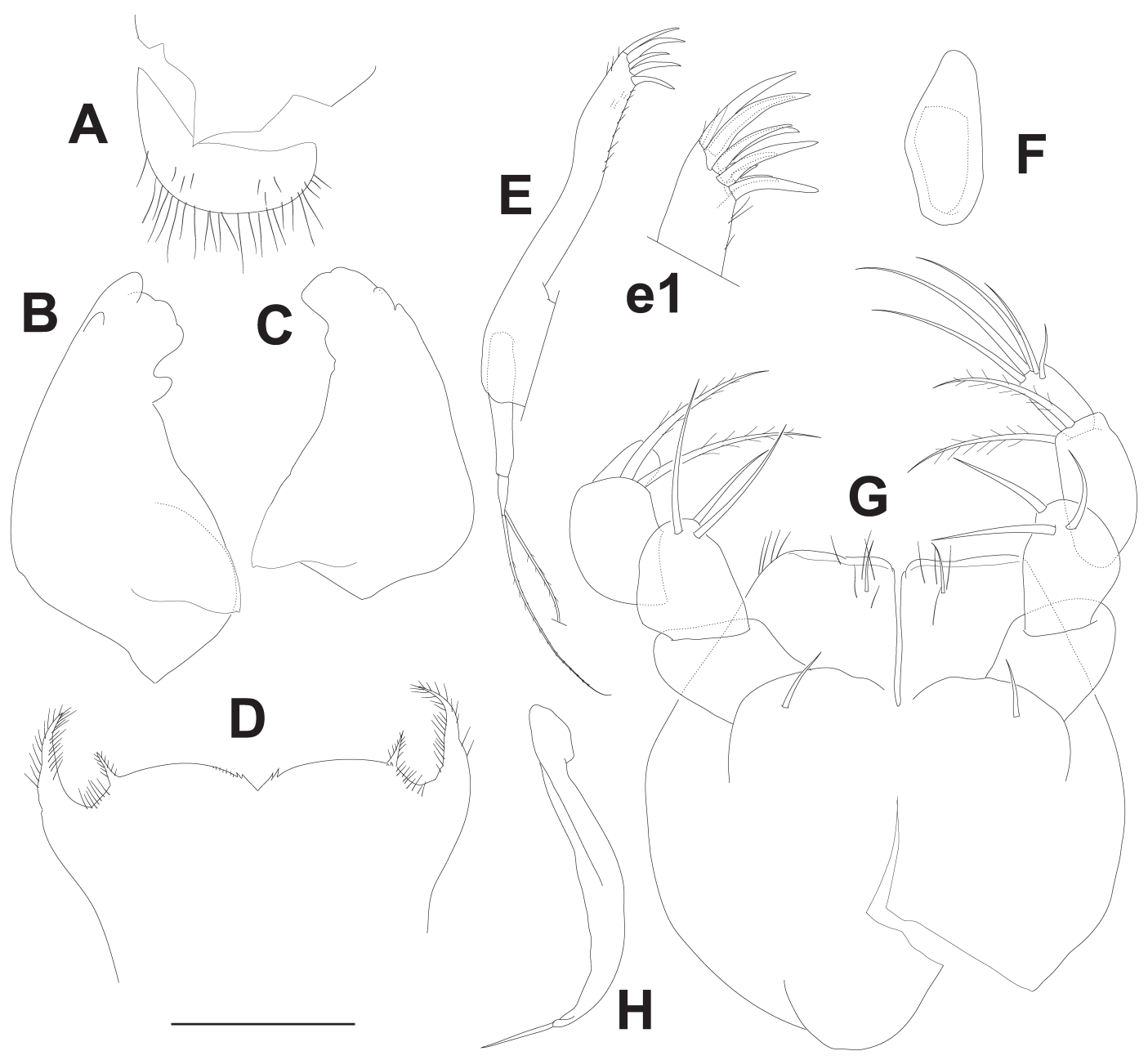

Fig. 12. Agathotanais toyoshioae sp. nov., holotype, female. A, labrum (broken); B, left mandible; C, right mandible; D, labium; E, right maxillule; e1, same, tip of endite; F, right maxilla; G, maxillipeds (body partly broken; setae on right palp-article 4 omitted); $\mathrm{H}$, right epignath. Scale bar: A-D, e1, G, $0.05 \mathrm{~mm}$; E, F, H, $0.1 \mathrm{~mm}$.

tral simple setae. Merus with two ventral simple setae. Carpus with one inner simple seta and one ventrodistal spiniform seta. Propodus with three distal spiniform setae. Dactylus naked. Unguis with row of short setae. Pereopod 5 (Fig. 13E) with length ratio of articles from basis to dactylus-unguis 4.90:0.30:1.00: $1.40: 1.30: 2.35$; similar to pereopod 4 , except basis with two dorsal PSS. Pereopod 6 (Fig. 13F) with length ratio of articles from basis to dactylus-unguis $4.45: 0.30: 1.00: 1.50$ : $1.20: 2.25$; similar to pereopod 5 , except basis with one dorsal and one ventral PSS.

Pleopods absent.

Uropod (Fig. 13G) with exopod fused to basal article, slight, not expanded laterally, bearing two simple setae. Endopod fused to basal article, with four simple setae and four PSS.

Distribution. So far known only from type locality.

Remarks. Agathotanais toyoshioae sp. nov. is the eleventh species described in this genus. Seven congeners similarly have a uniarticulate antenna and uropods without articulations between the basal article and the tip. Among these, A. toyoshioae most closely resembles A. spinipoda
Larsen, 1999 in having: 1) all pleonites narrower than pereonite 6 ; 2) a short dorsodistal simple seta on the carpus of pereopod 2 (shorter than two-thirds of the propodus length); and 3) the carpus and propodus of pereopods 4-6 with one and three distal spiniform setae, respectively. Agathotanais toyoshioae differs from A. spinipoda in having 1) narrower pleonites (i.e., pleonite width 0.65 times width of pereonite 6 and 0.45 times $\mathrm{CW}$ in A. toyoshioae, but 0.75 times and 0.65 times respectively in A. spinipoda); 2) a ventral keel on pleonites 1 and $2 ; 3$ ) the bases of pereopods 1-6 with dorsal small spines; and 4) no ventral small spines on the carpus and propodus of pereopods 4-6 (see Larsen 1999b).

\section{Key to the species of Agathotanais (females)}

1. Antenna with two articles. A. manganicus Larsen, 1999

- Antenna with one article

2. Uropod with one articulation between basal article and tip 


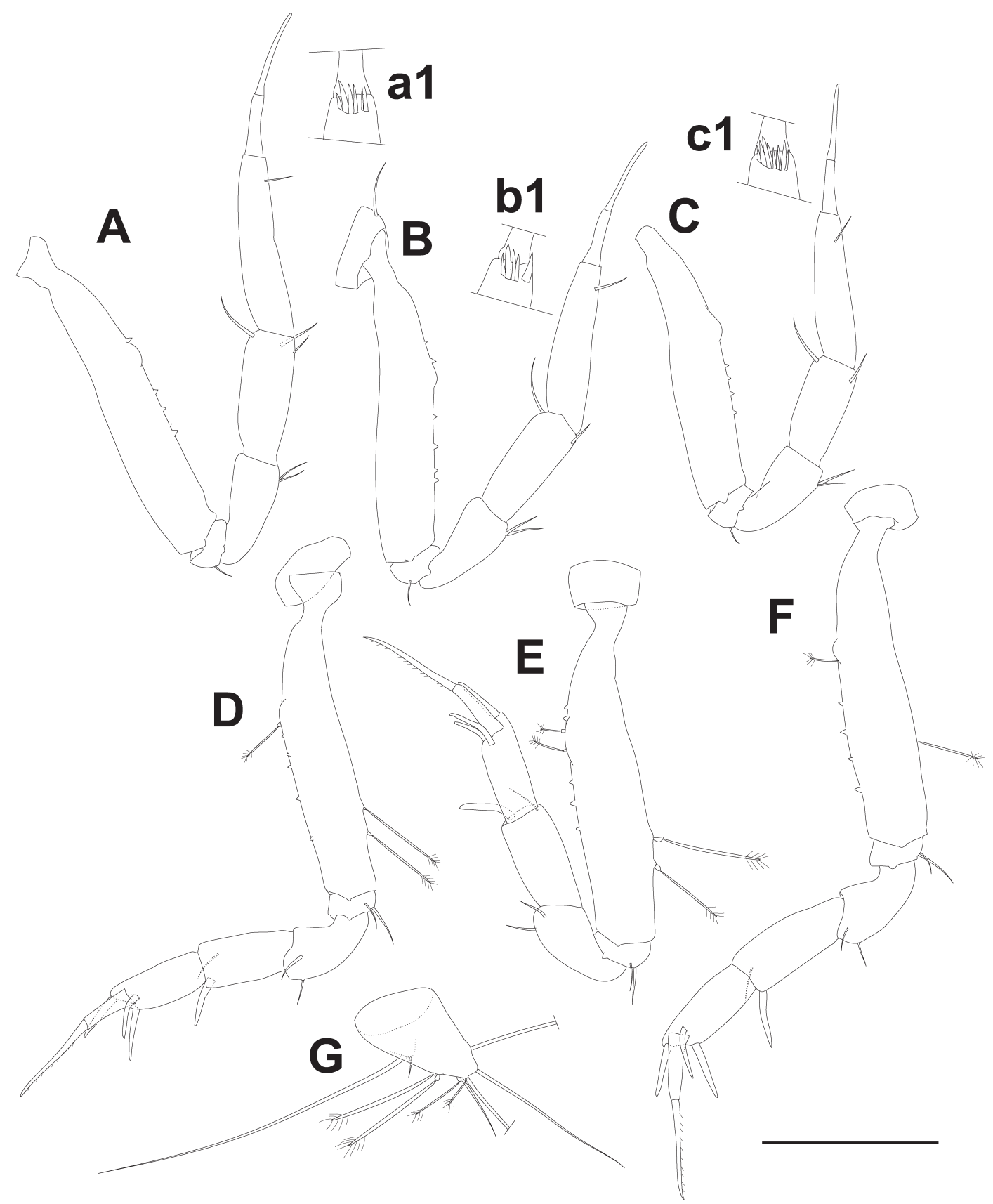

Fig. 13. Agathotanais toyoshioae sp. nov., holotype, female. A-F, right pereopods 1-6, outer views; a1, b1, c1, distal parts of propodi of pereopods 1-3, respectively, inner views; G, right uropod. Scale bar: A-G, $0.1 \mathrm{~mm}$; a1, b1, c1, $0.05 \mathrm{~mm}$.

- Uropod without articulations between basal article and tip.......

3. Length/width of pereonites 3 and 4 about 1.50; pleonites as wide as pereonite 6 . A. ghilarovi

- $\quad$ Length/width of pereonites 3 and 4 almost 1.00; pleonites narrower than pereonite 6 ...... misakiensis sp. nov.

4. Fixed finger with two ventral simple setae; carpus of pereopods 1-3 lacking dorsodistal seta; pleonites narrower than pereonite 6 A. ahyongi Larsen, 1999

- $\quad$ Fixed finger without ventral seta; carpus of pereopods 1 and 3 (no data for pereopod 2) with one dorsodistal seta; pleonites as wide as pereonite 6 .......... A. splendidus

- $\quad$ Fixed finger with one ventral simple seta; carpus of pereopods 1-3 with one dorsodistal seta; pleonites nar- rower than pereonite 6 5

5. Dorsodistal simple seta on carpus of pereopod 2 long (longer than two-thirds of propodus length).

- Dorsodistal simple seta on carpus of pereopod 2 short (shorter than two-thirds of propodus length)

6. Body stout (BL/CW 5.30); cephalothorax length equal to $\mathrm{CW}$. A. brevis Kudinova-Pasternak, 1990

- Body narrow (BL/CW more than 6.50); cephalothorax length longer than $\mathrm{CW}$ 7

7. Pereonite 3 shorter than wide, pereonite 4 longer than wide (length/width 0.90 and 1.10, respectively); dactylus of pereopods 1-3 naked. A. ingolfi

- Pereonites 3 and 4 longer than wide (length/width 1.15 and 1.30, respectively); dactylus of pereopods $1-3$ with 

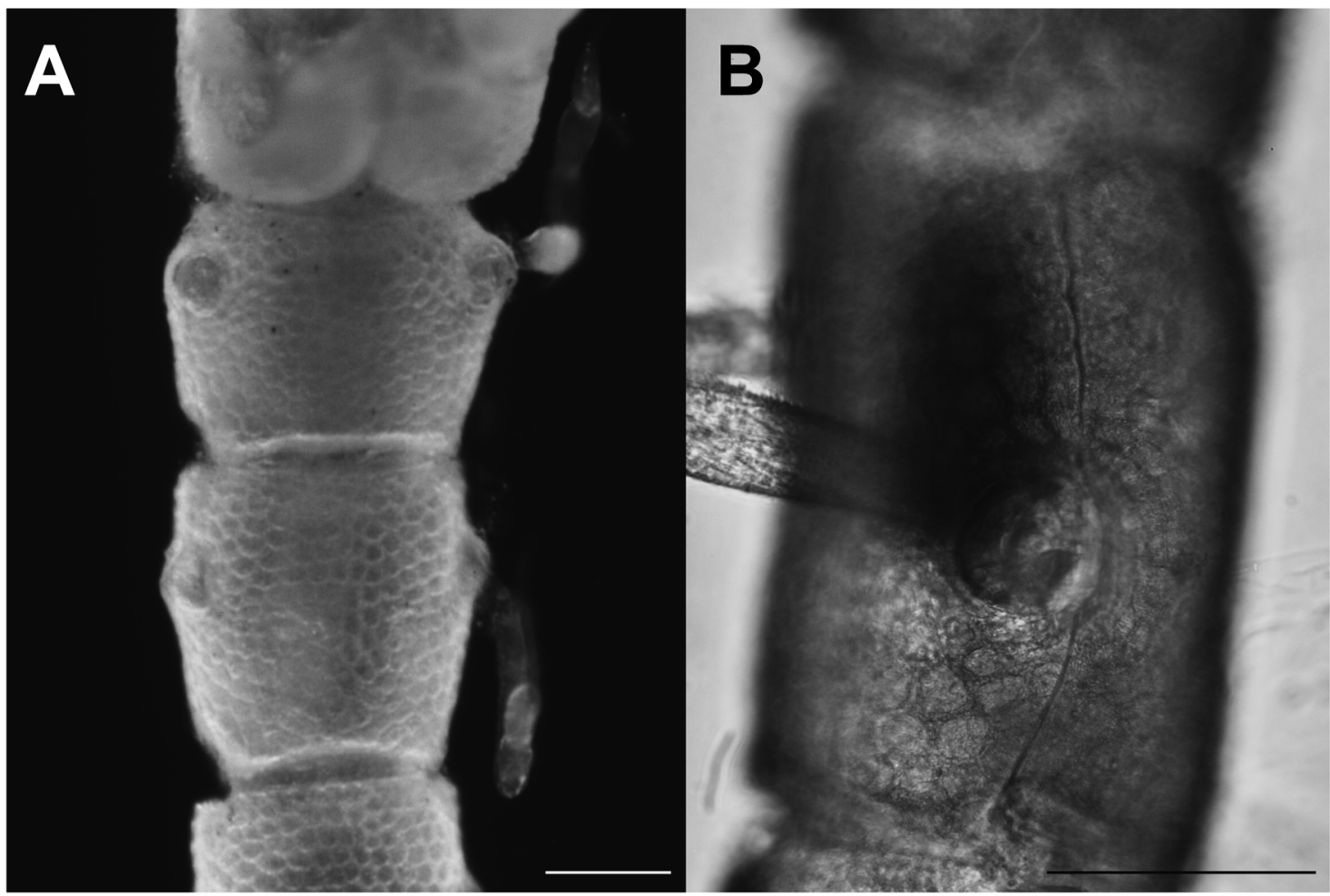

Fig. 14. Agathotanais toyoshioae sp. nov., holotype, female, microphotographs showing pitted surface. A, pereonites 1 and 2, image from stereoscopic microscope, ventral view; B, pereonite 4, image from compound microscope, left view. Scale bars: $0.1 \mathrm{~mm}$.

one simple seta

A. hanseni Lang, 1971

8. Carpus and propodus of pereopods $4-6$ with three and two distal spiniform setae, respectively A. hadalis

- Carpus and propodus of pereopods 4-6 with one and three distal spiniform setae, respectively..... .... 9

9. Pleonites narrow (pleonite width 0.75 times pereonite- 6 width and 0.65 times $\mathrm{CW}$ ); basis of pereopods 1-6 without dorsal small spines; carpus and propodus of pereopods 4-6 with ventral small spines.

..A. spinipoda

- Pleonites very narrow (pleonite width 0.65 times pereonite- 6 width and 0.45 times $\mathrm{CW}$ ); basis of pereopods 1-6 with dorsal small spines; carpus and propodus of pereopods 4-6 without ventral small spines.

A. toyoshioae sp. nov.

\section{Acknowledgments}

We thank Susumu Ohtsuka and Michitaka Shimomura for providing several specimens; Mamoru Sekifuji for help in sampling aboard RV Rinkai-maru; Captain Kazumitsu Nakaguchi and the crew of TRV Toyoshio-maru for support during the cruise in 2014; Hiroshi Kajihara for providing laboratory facilities; Matthew H. Dick for reviewing and editing the manuscript; and the Japanese Association for Marine Biology (JAMBIO) Coastal Organism Joint Survey for contributing specimens. The map and plots were generated with GMT5 software (Wessel et al. 2013). This work was supported in part by a research grant from JAMBIO (Project
No. 23-28).

\section{References}

Barnard, K. H. 1920. Contributions to the crustacean fauna of South Africa. Annals of the South African Museum 17: 319-438, pls XV-XVII.

Bird, G. J. 2010. Tanaidacea (Crustacea, Peracarida) of the North-east Atlantic: the Agathotanaidae of the AFEN, BIOFAR and BIOICE projects, with a description of a new species of Paragathotanais Lang. Zootaxa 2730: 1-22.

Bird, G. J. 2011. Paratanaoidean tanaidaceans (Crustacea: Peracarida) from littoral and shallow sublittoral habitats in New Zealand, with descriptions of three new genera and seven new species. Zootaxa 2891: 1-62.

Bird, G. J. and Holdich, D. M. 1988. Deep-sea Tanaidacea (Crustacea) of the North-east Atlantic: the tribe Agathotanaini. Journal of Natural History 22: 1591-1621.

Błażewicz-Paszkowycz, M. and Bamber, R. N. 2012. The shallow-water Tanaidacea (Arthropoda: Malacostraca: Peracarida) of the Bass Strait, Victoria, Australia (other than the Tanaidae). Memoirs of Museum Victoria 69: 1-235.

Hansen, H. J. 1913. Crustacea Malacostraca. II. IV. The order Tanaidacea. The Danish Ingolf Expedition 3: 1-145.

Holdich, D. M. and Jones, J. A. 1983. The distribution and ecology of British shallow-water tanaid crustaceans (Peracarida, Tanaidacea). Journal of Natural History 17: 157-183.

Jóźwiak, P. and Jakiel, A. 2012. A new genus and new species of Agathotanaidae (Crustacea, Tanaidacea) from West Australia. Zookeys 243: $15-26$

Kakui, K. and Angsupanich, S. 2012. Birdotanais songkhlaensis, a new 
genus and species of Nototanaidae (Crustacea: Tanaidacea) from Thailand. The Raffles Bulletin of Zoology 60: 421-432.

Kudinova-Pasternak, R. K. 1970. [Tanaidacea of the Kurile-Kamchatka Trench]. Trudy Instituta Okeanologii 86: 341-381. [In Russian]

Kudinova-Pasternak, R. K. 1989. Tanaidaceés abyssales (Crustacea, Tanaidacea) des parties nord-est et centrale de l'Ocean Indian (d'après des matériaux de l'expedition Française "Safari-II") 2. Sous-ordre Tanaidomorpha. Zoologicheskii Zhurnal 68: 27-40. [in Russian with French summary]

Kudinova-Pasternak, R. K. 1990. Tanaidacea (Crustacea, Malacostraca) of the southeastern part of Atlantic Ocean and the region to the north off Mordvinov (Elephant) Island. Trudy Instituta Okeanologii 126: 90-107. [in Russian with English summary]

Lang, K. 1971. Die Gattungen Agathotanais Hansen und Paragathotanais $\mathrm{n}$. gen. (Tanaidacea). Crustaceana 21: 57-71.

Larsen, K. 1999a. Deep-sea tanaidaceans (Crustacea: Peracarida) from the Albatross cruises 1885-86 with keys to the suborder Neotanaidomorpha. Journal of Natural History 33: 1107-1132.

Larsen, K. 1999b. Pacific Tanaidacea (Crustacea): revision of the genus Agathotanais with description of three new species. Records of the Australian Museum 51: 99-112.

Larsen, K. 2003. Proposed new standardized anatomical terminology for the Tanaidacea (Peracarida). Journal of Crustacean Biology 23: 644-661.

Larsen, K. 2005. Deep-Sea Tanaidacea (Crustacea; Peracarida) from the Gulf of Mexico. Brill, Leiden, $\mathrm{x}+382 \mathrm{pp}$.

Larsen, K. 2007. Family Agathotanaidae Lang, 1971a. Zootaxa 1599: 41-60.

Wessel, P., Smith, W. H. F., Scharroo, R., Luis, J., and Wobbe, F. 2013. Generic Mapping Tools: improved version released. Eos, Transactions American Geophysical Union 94: 409-410. 